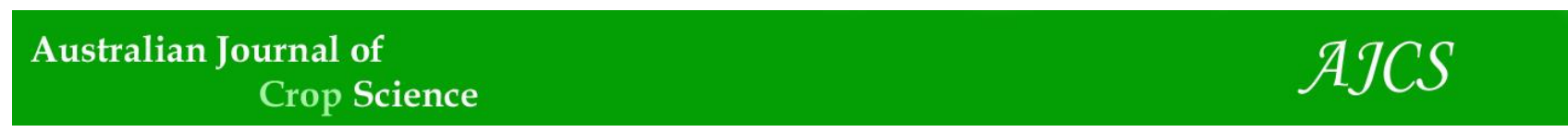

AJCS 12(02):178-184 (2018)

ISSN:1835-2707

doi: 10.21475/ajcs.18.12.02.pne476

\title{
Effect of biochar and nutrient amendment on vegetative growth of spring barley (Hordeum vulgare L. var. Malz)
}

\author{
Elena Kondrlova*, Jan Horak, Dusan Igaz
}

Department of Biometeorology and Hydrology, Slovak University of Agriculture, Hospodarska 7, Nitra, 94976, Slovakia

\section{*Corresponding author: elena.kondrlova@gmail.com; elena.kondrlova@uniag.sk}

\section{Abstract}

We tried to determine whether a commercially available, amended biochar could potentially increase the growth and yield of spring barley (Hordeum vulgare L. var. Malz) on loamy soil located in western Slovakia in 2014. Treatments $(n=15)$ with three replications consisted of a control, raw biochar $(\mathrm{RB})\left(0,10,20 \mathrm{t} \mathrm{ha}^{-1}\right)$ and nitrogen-enriched biochar+compost $(\mathrm{EB})\left(0,10,20 \mathrm{tha} \mathrm{C}^{-1}\right)$ application, combined with 3 levels of mineral fertilization $\left(0,40,80 \mathrm{~kg} \mathrm{~N} \mathrm{ha}^{-1}\right)$. The plots $(4 \mathrm{~m} \times 6 \mathrm{~m})$ were organized in randomized block design. We examined above and below-ground biomass, crop height, number of plants per $\mathrm{m}^{2}$, grain yield and plant canopy development determined from digital image-derived vegetation indices. The positive effect of biochar application on the plant canopy development was observed. In case of the vegetation index, the difference between the treatments and control rose in the following order at all fertilization levels $\left(0,40,80 \mathrm{~kg} \mathrm{ha}^{-1}\right)$ : control <RB $\left(10 \mathrm{tha}^{-1}\right)<\mathrm{RB}\left(20 \mathrm{t} \mathrm{ha}^{-1}\right)<\mathrm{EB}\left(10 \mathrm{t} \mathrm{ha} \mathrm{a}^{-1}\right)<\mathrm{EB}\left(20 \mathrm{t} \mathrm{ha}{ }^{-1}\right)$. Ten and twenty $\mathrm{t} \mathrm{ha}^{-1}$ of EB without fertilizer increased root biomass by 126 and $52 \%$, and above-ground biomass by 62 and $36 \%$, respectively. We conclude that a single EB application of $10 \mathrm{t} \mathrm{ha}^{-1}$ or $20 \mathrm{t} \mathrm{ha}^{-1}$ (even if applied without $\mathrm{N}$ fertilizer) can increase plant biomass on loamy Typic Hapludalfs at least in the first cropping season.

Keywords: agro-ecosystem; biochar; plant biomass; crop yield; fertilizer; soil amendment; spring barley.

Abbreviations: EB_enriched biochar; GF_green fraction; IDVI_image-derived vegetation index; N_nitrogen fertilizer; RB_raw biochar.

\section{Introduction}

The increasing need for providing food for growing population is leading to conversion of natural landscapes to agricultural land, while simultaneously depleting quantity and quality of land currently under agricultural use (Lal, 2009). Therefore improved practices for increased food production are urgently needed to lower this pressure on soils, in order to decrease or prevent the negative environmental impacts of intensive agriculture (Fisher and Glaser, 2012) while offering the potential to improve soil fertility and crop yields by application of sustainable intensification techniques (UNEP, 2012). According to FAO (2015), sustainable agriculture aims to nurture healthy ecosystems and support sustainable management of land, water and natural resources, while ensuring world food security. To be sustainable, agriculture must meet the needs of present and future generations for its products and services, while ensuring profitability, environmental health plus social and economic equity, as well as maintaining soil and water resources.

Various management practices have been developed to maintain the physical and chemical health of soils for high agricultural productivity. These include modified tillage (Bajgai et al., 2015), incorporation of organic matter (Mayer et al., 2015) and addition of various chemical (Duxbury et al., 2015) and organic based fertilizers (Mayer et al., 2015;
Delibacak and Ongun, 2016). Recently, the addition of biochar to soil has been found to have multiple benefits for soil conditions. It may also be a potential strategy for longterm carbon sequestration whilst improving the ecosystem services delivered by arable soils (Schulz and Glaser, 2012). Other benefits identified include combating global warming, and using waste material from agriculture and forestry (Alburquerque et al., 2013) or from domestic waste (Ramola et al., 2013). In terms of soil-quality improvement, several researchers have evaluated the role of biochar as a stable source of carbon and have shown it to affect positively soil properties and enhance crop yields (e.g. Lehman et al., 2006; Graber et al., 2010; Lin et al., 2015). Changes in hydrophysical soil properties, plant rooting patterns, as well as increased soil fauna occur, and are ascribed primarily to the lower density matrix of biochar relative to the mineral soil matrix (Ramola et al., 2013).

The exact form of biochar depends on its feedstock origin and processing. Hence biochar varies from region to region. Some feedstocks already used include rice straw, bamboo and wood chips (Liopa-Tsakalidy and Barouchas, 2017), wheat straw (Bruun et al., 2014) or soft- or hardwood from various tree species (Schulz et al., 2013; Bruun et al., 2014). Biochar, being predominately carbon, is low in nutrients. It has been suggested that combining it with either mineral 
(e.g. Alburquerque et al., 2013) or organic fertilizer (e.g. Ramola et al., 2013; Shulz et al., 2013; Vinh et al., 2014) would be advantageous for crop production. However, the fundamental mechanisms by which biochar affects crop growth are insufficiently understood (Sohi et al., 2010), and the results of research to date show large variability in crop response depending on the biochar type and experimental conditions (Alburquerque et al., 2013; Schulz et al., 2014). With commercially produced, fertilizer-amended biochar becoming available it is important that quantitative assessment be made of the possible effects on soils and crops.

Our study was designed to investigate the potential effects of biochar and fertilizer addition on spring barley (Hordeum vulgare L. var. Malz) productivity during the vegetative season. The experimental site was located on Typic Hapludalfs that is an important agricultural soil type of Slovakia, and is generally representative of many productive soils in central Europe. We hypothesized that biochar addition would (1) increase barley productivity and that (2) biochar addition would interact positively with the addition of mineral and organic fertilizers for plant productivity.

\section{Results and Discussion}

\section{Effect of biochar addition on plant canopy development}

There are few studies focusing on continuous monitoring of plant development under biochar application. The response we measured of plant development interpreted by I-DVI (image-derived vegetation index, $\mathrm{n}=$ subscript indicates the individual sampling dates) is shown in Table 1. From the tillering stage (I-DV| $\left.\left.\right|_{8.4}\right)$, up to beginning of stem elongation $\left(I-D V I_{24.4}\right)$, there were no significant differences in GF of spring barley after biochar application. However there were significant differences $(p<0.05)$ in the GF for EB at all fertilizer levels as the plants developed from I-DVI 24.4 . While the GF increased as the plants were developing, depending on increasing biomass and soil surface coverage, this ceased at the beginning of dough development $\left(I-D V I_{17.6 .}\right)$, as the plants began to mature and leaves begin to senesce.

From the beginning of tillering $\left(I-D V I_{8.4}\right)$ up to ear emergence (I-DVI 31.5.$)$, the overall plant canopy development decreased in the same order as fertilizer levels $(0,40,80 \mathrm{~kg}$ $\left.\mathrm{N} \mathrm{ha}{ }^{-1}\right): \mathrm{EB}\left(20 \mathrm{t} \mathrm{ha}^{-1}\right)>\mathrm{EB}\left(10 \mathrm{tha}^{-1}\right)>\mathrm{RB}\left(20 \mathrm{t} \mathrm{ha}^{-1}\right)>\mathrm{RB}(10$ $\mathrm{t} \mathrm{ha}^{-1}$ ) > control. Treatment NO/RB10 was the only exception. It had up to $4 \%$ lower GF distribution compared to the control during this period. The highest increase in GF was observed for EB treatments. At $10 \mathrm{t} \mathrm{ha}^{-1}$, the GF increase ranged from 9 to $38 \%$, from 6 to $36 \%$ and from 11 to $25 \%$ in comparison to control when no fertilizer, $40 \mathrm{~kg} \mathrm{~N} \mathrm{ha}^{-1}$ and $80 \mathrm{~kg} \mathrm{~N} \mathrm{ha}^{-1}$ was applied, respectively. The EB applied at $20 \mathrm{t}$ ha $^{-1}$ resulted in GF increase from 27 to $66 \%$, from 29 to $56 \%$ and from 15 to $59 \%$ in comparison to control when no fertilizer, $40 \mathrm{~kg} \mathrm{~N} \mathrm{ha}^{-1}$ and $80 \mathrm{~kg} \mathrm{~N} \mathrm{ha}^{-1}$ was applied, respectively. I-DVI $\left.\right|_{31.5}$. was generally slightly lower for the majority of treatments in comparison with the earlier I-DVIs. Estimation of I-DVI using conventional digital camera proved to be an efficient tool for fast image sampling in the field. Morgounov et al. (2014) found out that normalized difference vegetation index (NDVI) and photo-a and photo-b parameters derived from Breedpix software had equal power in distinguishing genotypes of different yield in the trials. They were significantly associated with yield in approximately $50 \%$ of all observations used in the study. Nevertheless, this technique has limitations. Firstly, as the GF is calculated as a count of green pixels per image, one has to be sure that it includes only plants of interest and not weeds. Secondly, it is limited by time period when the canopy is suitably green for photo sampling. This period depends on the life cycle of individual crops. At the end of leaf emergence (Boys and Geary, 2015), green color of canopy begins to reduce. In our study, after grain milk development, the plants were becoming more yellowish, hence the determination of GF did not correspond well to plant biomass and the estimated I-DVI ${ }_{17.6}$. was lower than expected. Therefore, regarding spring barley, we suggest curtailing the photo observation just up to grain milk development.

\section{Effect of biochar addition on total number of plants and plant height}

The total number of plants (Table 2) was lower than the control for treatments without fertilization (by $4 \%$ up to 22 $\%$ ) except at NO/RB20, where $8 \%$ more plants per $\mathrm{m}^{2}$ were grown. At $40 \mathrm{~kg} \mathrm{~N}^{-1}$ the number of plants decreased by 2 $\%$ (N40/RB20) up to $20 \%$ (N40/EB20), while in contrast it increased at $80 \mathrm{~kg} \mathrm{~N} \mathrm{ha}^{-1}$ by $12 \%$ (N80/RB20) to $36 \%$ (N80/EB10).

Application of both biochar types generally increased crop height (Table 2). While for RB the positive effect was observed at $80 \mathrm{~kg} \mathrm{~N} \mathrm{ha}^{-1}$ application rate (increase by $4 \%$ and $15 \%$ for N80/RB10 and N80/RB20, respectively). The EB treatment showed the best response at $40 \mathrm{~kg} \mathrm{~N} \mathrm{ha}^{-1}$ and at plots without $\mathrm{N}$ fertilizer. The plant height increased significantly ( $<<0.05$ ) by $10 \%$ up to $34 \%$ for N40/EB10 and N40/EB2O and by $24 \%$ up to $29 \%$ for NO/EB2O and No/EB10, respectively.

\section{Effect of biochar addition on above-ground and root biomass}

The effect of biochar application on above-ground biomass is shown in Table 2. There was an increase of 4, 22, 62 and $36 \%$ in comparison to control for NO/RB10, NO/RB20, NO/EB10 and NO/EB2O, respectively. Higher above-ground biomass was observed also after fertilizer application: by 31 $\%$ and $26 \%$ (N40/EB10 and N40/EB20); and by $10 \%$ and 24 $\%$ (N80/RB10 and N80/EB20), respectively, although the magnitude of the increase was not corresponding to increasing fertilizer amount.

After EB application, at all fertilizer levels, the root biomass (Table 2) increased from $4 \%$ (N80/EB10) up to 126 $\%$ (N0/EB10). In contrast, a decrease was observed after RB application from $0.4 \%$ (N80/RB10) up to $43 \%$ (N40/RB10).

\section{Effect of biochar addition on plant grain yield}

The final grain yield increased significantly from $5.3 \mathrm{tha}^{-1}$ up to $6.2 \mathrm{t} \mathrm{ha}^{-1}$ for treatments with enriched biochar, when no fertilizer or $40 \mathrm{~N} \mathrm{ha}^{-1}$ were applied which is an increase in the final grain yield by $43 \%$ (N40/EB10) up to $78 \%$ (NO/EB20).

Both biochar types increased above-ground biomass when no fertilizer was applied. The EB treatment increased plant growth-including crop height, above-ground and below 
Table 1. Plant canopy development according to the image-derived vegetation indices (I-DVI) estimated by photographic sampling at different sampling dates.

\begin{tabular}{|c|c|c|c|c|c|c|c|c|}
\hline $\begin{array}{l}\text { Treatment } \\
\text { acronym }\end{array}$ & I-DVI $\left.\right|_{8.4 .}(\%)$ & $\mathrm{I}^{-D V I_{15.4 .}(\%)}$ & $I^{\prime}-\mathrm{DVI}_{24.4 .}(\%)$ & $\left.\mathrm{I}^{-D V I}\right|_{1.5}(\%)$ & $\mathrm{I}^{-D V I} \mathrm{I}_{7.5}(\%)$ & I-DVI $21.5 .(\%)$ & I-DVI $\left.\right|_{31.5 .}(\%)$ & I-DVI $17.6 .(\%)$ \\
\hline No/RB10 & $8.4 \pm 1.3^{a}$ & $15.0 \pm 3.4^{a}$ & $27.2 \pm 4.9^{a}$ & $47.9 \pm 4.7^{a}$ & $51.2 \pm 5.3^{a}$ & $54.1 \pm 5.0^{\mathrm{a}}$ & $56.2 \pm 4.1^{a}$ & $19.4 \pm 3.0^{\mathrm{a}}$ \\
\hline NO/EB10 & $9.1 \pm 0.6^{\mathrm{a}}$ & $17.0 \pm 1.9^{a}$ & $34.8 \pm 2.6^{a}$ & $61.7 \pm 1.9^{b c}$ & $68.6 \pm 1.6^{b^{*}}$ & $76.0 \pm 1.2^{b^{*}}$ & $74.8 \pm 1.3^{b^{*}}$ & $25.9 \pm 4.2^{\mathrm{a}}$ \\
\hline NO/EB2O & $10.5 \pm 1.2^{\mathrm{a}}$ & $22.9 \pm 3.0^{a}$ & $47.2 \pm 4.8^{b^{*}}$ & $70.7 \pm 2.6^{\mathrm{c}^{*}}$ & $77.4 \pm 2.1^{\mathrm{b}^{*}}$ & $81.5 \pm 1.9^{b^{*}}$ & $78.1 \pm 1.2^{b^{*}}$ & $18.7 \pm 4.8^{a}$ \\
\hline N40/B0 & $9.5 \pm 1.2^{\mathrm{a}}$ & $17.6 \pm 1.5^{a}$ & $30.5 \pm 2.9^{a}$ & $53.5 \pm 4.3^{\mathrm{a}}$ & $54.5 \pm 3.3^{\mathrm{a}}$ & $62.4 \pm 2.7^{\mathrm{a}}$ & $58.4 \pm 3.9^{a}$ & $11.9 \pm 1.5^{\text {ab }}$ \\
\hline N40/EB10 & $10.1 \pm 0.9^{a}$ & $20.8 \pm 3.0^{a}$ & $40.3 \pm 3.8^{a}$ & $65.7 \pm 3.9^{\mathrm{ab}}$ & $70.6 \pm 3.3^{b^{*}}$ & $78.0 \pm 1.3^{b^{*}}$ & $77.6 \pm 1.5^{b^{*}}$ & $20.1 \pm 3.6^{b c}$ \\
\hline N40/EB20 & $12.3 \pm 1.3^{\mathrm{a}}$ & $23.2 \pm 2.5^{a}$ & $47.6 \pm 3.7^{\mathrm{a}}$ & $72.8 \pm 3.1^{b^{*}}$ & $79.7 \pm 1.7^{c^{*}}$ & $80.5 \pm 1.5^{b^{*}}$ & $82.2 \pm 2.0^{b^{*}}$ & $25.4 \pm 1.5^{c^{*}}$ \\
\hline N80/B0 & $8.9 \pm 1.1^{a}$ & $19.0 \pm 2.5^{a}$ & $35.3 \pm 4.3^{\mathrm{a}}$ & $55.3 \pm 5.4^{\mathrm{a}}$ & $57.4 \pm 6.3^{\mathrm{a}}$ & $71.0 \pm 4.7^{\mathrm{a}}$ & $70.0 \pm 2.7^{a}$ & $18.5 \pm 5.9^{\mathrm{a}}$ \\
\hline N80/RB10 & $10.7 \pm 0.6^{a}$ & $20.2 \pm 1.8^{a}$ & $38.3 \pm 2.7^{\mathrm{a}}$ & $60.8 \pm 2.5^{a}$ & $64.5 \pm 1.8^{\mathrm{ab}}$ & $71.8 \pm 1.6^{a}$ & $71.6 \pm 1.9^{\mathrm{ab}}$ & $14.4 \pm 4.4^{\mathrm{a}}$ \\
\hline N80/RB20 & $11.5 \pm 0.9^{a}$ & $20.2 \pm 2.3^{a}$ & $40.1 \pm 3.3^{a}$ & $62.6 \pm 3.2^{\mathrm{a}}$ & $67.3 \pm 2.2^{\mathrm{b}^{*}}$ & $74.1 \pm 2.6^{\mathrm{ab}}$ & $72.6 \pm 2.5^{\mathrm{ab}}$ & $12.3 \pm 1.7^{\mathrm{a}}$ \\
\hline N80/EB10 & $11.1 \pm 1.0^{\mathrm{a}}$ & $22.6 \pm 2.4^{a}$ & $43.4 \pm 3.8^{\mathrm{a}}$ & $66.8 \pm 3.3^{\mathrm{ab}}$ & $71.6 \pm 2.0^{b c^{*}}$ & $80.5 \pm 1.9^{b c^{*}}$ & $77.8 \pm 1.1^{b c^{*}}$ & $18.5 \pm 4.1^{\mathrm{a}}$ \\
\hline
\end{tabular}

All values represent means \pm SEM ( $n=6)$. Different superscript letters represent significant differences between treatments at the $P \leq 0.05$ level (Fisher's least significant difference test). ${ }^{*}$ indicates one-way ANOVA results of $\mathrm{P} \leq 0.05$. Different subscript numbers associated with I-DVI represent the sampling date.

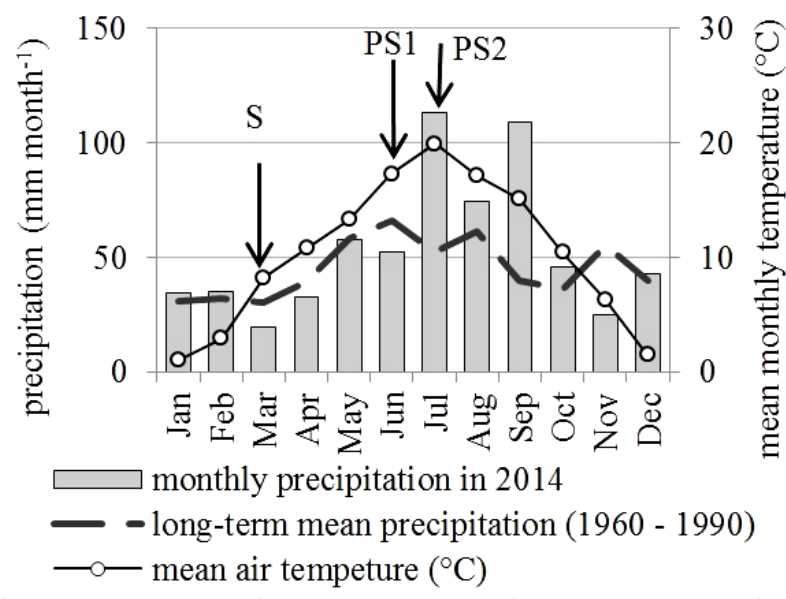

Fig 1. Monthly precipitation and mean air temperature at Malanta in 2014 compared to the mean long-term precipitation (1960 1990). $S$ = sowing (11.3.2014), PS1 = plant sampling (14.6.2014), PS2 = plant sampling (14.7.2014).

Table 2. Influence of two types of biochar applied at different rates on crop growth in combination with three fertilization levels.

\begin{tabular}{|c|c|c|c|c|c|}
\hline $\begin{array}{l}\text { Treatment } \\
\text { acronym }\end{array}$ & $\begin{array}{c}\text { Plant height } \\
\text { (cm) }\end{array}$ & $\begin{array}{l}\text { Number of } \\
\text { plants } \\
\text { (plant } \mathrm{m}^{-2} \text { ) }\end{array}$ & $\begin{array}{c}\text { Above-ground dry } \\
\text { Biomass (at } 85 \% \text { of DM) } \\
\text { (t ha }{ }^{-1} \text { ) }\end{array}$ & $\begin{array}{c}\text { Root } \\
\text { biomass } \\
\left(\mathrm{t} \mathrm{ha}^{-1}\right)\end{array}$ & $\begin{array}{c}\text { Final grain } \\
\text { yield } \\
\left(\mathrm{t} \mathrm{ha} \mathrm{h}^{-1}\right)\end{array}$ \\
\hline NO/BO & $45.87 \pm 3.2^{\mathrm{a}}$ & $261 \pm 14.1^{\mathrm{a}}$ & $10.0 \pm 1.6^{\mathrm{a}}$ & $0.66 \pm 0.0^{\mathrm{ab}}$ & $3.6 \pm 0.8^{a}$ \\
\hline N0/RB10 & $45.08 \pm 2.9^{\mathrm{a}}$ & $251 \pm 21.3^{\mathrm{a}}$ & $10.4 \pm 3.0^{a}$ & $0.57 \pm 0.2^{\mathrm{a}}$ & $5.1 \pm 0.9^{\mathrm{ab}}$ \\
\hline NO/RB20 & $45.79 \pm 3.2^{\mathrm{a}}$ & $283 \pm 61.5^{a}$ & $12.2 \pm 2.3^{\mathrm{a}}$ & $0.56 \pm 0.1^{\mathrm{a}}$ & $3.2 \pm 0.5^{\mathrm{a}}$ \\
\hline N0/EB10 & $59.10 \pm 2.8^{\mathrm{b}} *$ & $229 \pm 14.1^{\mathrm{a}}$ & $16.2 \pm 3.4^{\mathrm{a}}$ & $1.48 \pm 0.1^{\mathrm{c}} *$ & $6.0 \pm 0.5^{b} *$ \\
\hline NO/EB2O & $56.78 \pm 3.8^{\mathrm{b}} *$ & $203 \pm 59.4^{\mathrm{a}}$ & $13.6 \pm 3.1^{\mathrm{a}}$ & $1.00 \pm 0.2^{b}$ & $6.4 \pm 0.1^{b} *$ \\
\hline N40/B0 & $47.00 \pm 1.8^{\mathrm{ab}}$ & $267 \pm 32.4^{\mathrm{a}}$ & $10.1 \pm 1.2^{\mathrm{a}}$ & $0.87 \pm 0.1^{a}$ & $3.7 \pm 0.5^{\mathrm{a}}$ \\
\hline N40/RB10 & $44.49 \pm 1.6^{\mathrm{a}}$ & $245 \pm 5.3^{\mathrm{a}}$ & $7.7 \pm 0.4^{\mathrm{a}}$ & $0.49 \pm 0.1^{\mathrm{a}}$ & $3.9 \pm 0.2^{\mathrm{a}}$ \\
\hline N40/RB20 & $47.64 \pm 2.5^{\mathrm{ab}}$ & $261 \pm 28.2^{\mathrm{a}}$ & $9.0 \pm 0.4^{\mathrm{a}}$ & $0.62 \pm 0.1^{\mathrm{a}}$ & $3.6 \pm 0.5^{\mathrm{a}}$ \\
\hline N40/EB10 & $51.88 \pm 1.2^{b}$ & $235 \pm 29.7^{\mathrm{a}}$ & $13.2 \pm 1.9^{a}$ & $1.19 \pm 0.2^{\mathrm{a}}$ & $5.3 \pm 1.1^{\mathrm{ab}}$ \\
\hline N40/EB20 & $63.12 \pm 3.8^{\mathrm{c}} *$ & $213 \pm 10.7^{\mathrm{a}}$ & $12.8 \pm 2.6^{a}$ & $1.15 \pm 0.2^{\mathrm{a}}$ & $6.2 \pm 0.2^{\mathrm{b}} *$ \\
\hline N80/B0 & $51.65 \pm 0.9^{\mathrm{a}}$ & $176 \pm 18.5^{a}$ & $12.4 \pm 1.0^{\mathrm{a}}$ & $0.93 \pm 0.1^{\mathrm{a}}$ & $5.0 \pm 0.3^{\mathrm{a}}$ \\
\hline N80/RB10 & $53.53 \pm 2.4^{\mathrm{a}}$ & $203 \pm 19.2^{\mathrm{a}}$ & $13.6 \pm 4.5^{a}$ & $0.92 \pm 0.2^{\mathrm{a}}$ & $5.4 \pm 0.9^{\mathrm{a}}$ \\
\hline N80/RB20 & $59.40 \pm 6.0^{\mathrm{a}}$ & $197 \pm 19.2^{\mathrm{a}}$ & $8.7 \pm 1.4^{\mathrm{a}}$ & $0.77 \pm 0.1^{\mathrm{a}}$ & $4.9 \pm 0.4^{a}$ \\
\hline N80/EB10 & $55.38 \pm 1.6^{\mathrm{a}}$ & $240 \pm 27.7^{a}$ & $10.9 \pm 0.7^{a}$ & $0.96 \pm 0.0^{\mathrm{a}}$ & $6.9 \pm 0.4^{a}$ \\
\hline N80/EB20 & $56.04 \pm 2.3^{a}$ & $208 \pm 24.4^{\mathrm{a}}$ & $15.4 \pm 1.2^{\mathrm{a}}$ & $1.28 \pm 0.3^{\mathrm{a}}$ & $5.2 \pm 1.4^{a}$ \\
\hline
\end{tabular}

All values represent means \pm SEM ( $n=3$ ). Different superscript letters represent significant differences between treatments at the $P \leq 0.05$ level (Fisher's least significant difference test). ${ }^{*}$ indicates one-way ANOVA results of $\mathrm{P} \leq 0.05$. 


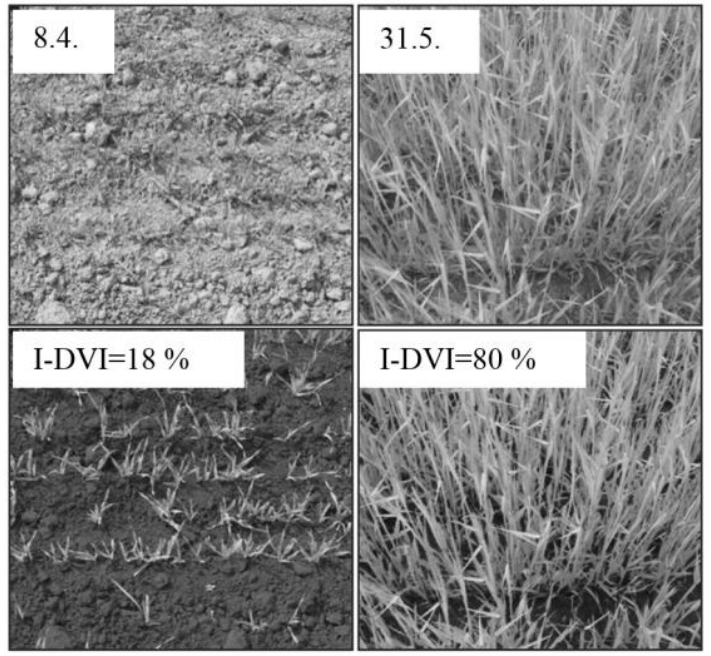

Fig 2. Example of input images taken from the same subplot at different dates in 2014 (top row) and relevant output images from BreedPix with estimated image-derived vegetation indices (I-DVI) (bottom row).

Table 3. Initial soil properties at the experimental site.

\begin{tabular}{lccccccc}
\hline Soil depth $(\mathrm{cm})$ & $\begin{array}{c}\mathrm{SOC} \\
\left(\mathrm{g} \mathrm{kg}^{-1}\right)\end{array}$ & $\mathrm{pH}(\mathrm{KCl})$ & $\begin{array}{c}\mathrm{N}-\mathrm{NO}_{3} \\
\left(\mathrm{mg} \mathrm{kg}^{-1}\right)\end{array}$ & $\begin{array}{c}\mathrm{N}-\mathrm{NH}_{4} \\
\left(\mathrm{mg} \mathrm{kg}^{-1}\right)\end{array}$ & $\begin{array}{c}\mathrm{N}-\mathrm{N}_{\text {tot }} \\
\left(\mathrm{mg} \mathrm{kg}^{-1}\right)\end{array}$ & $\begin{array}{c}\text { Texture } \\
\text { Bulk density } \\
\left(\mathrm{g} \mathrm{cm}^{-3}\right)\end{array}$ \\
\hline $0-10$ & 10.2 & 5.58 & 2.2 & 1.2 & 3.4 & loamy & 1.39 \\
$20-30$ & 8.1 & 5.84 & $\mathrm{n} / \mathrm{a}$ & $\mathrm{n} / \mathrm{a}$ & $\mathrm{n} / \mathrm{a}$ & loamy & $\mathrm{n} / \mathrm{a}$ \\
\hline n/a = data not available. & & & & & & &
\end{tabular}

$\mathrm{n} / \mathrm{a}=$ data not available.

Table 4. List of treatments used in the experiment (individual rows) and the relevant dosage combination of $\mathrm{N}$-fertilizer and biochar applied (columns).

\begin{tabular}{|c|c|c|c|c|c|c|c|c|c|}
\hline \multirow{3}{*}{$\begin{array}{l}\text { Treatment } \\
\text { acronym }\end{array}$} & \multirow{2}{*}{\multicolumn{3}{|c|}{$\begin{array}{l}\mathrm{N} \text {-fertilizer dosage } \\
\left(\mathrm{kg} \mathrm{ha}^{-1}\right)\end{array}$}} & \multicolumn{6}{|c|}{$\begin{array}{l}\text { Biochar type and dosage } \\
\left(\mathrm{t} \mathrm{ha}^{-1}\right)\end{array}$} \\
\hline & & & & \multicolumn{3}{|c|}{ RB } & \multicolumn{3}{|c|}{ EB } \\
\hline & 0 & 40 & 80 & 0 & 10 & 20 & 0 & 10 & 20 \\
\hline NO/BO & $x$ & & & $x$ & & & $x$ & & \\
\hline N0/RB10 & $x$ & & & & $x$ & & $x$ & & \\
\hline NO/RB20 & $x$ & & & & & $x$ & $x$ & & \\
\hline N0/EB10 & $x$ & & & $x$ & & & & $x$ & \\
\hline NO/EB20 & & & & $x$ & & & & & $x$ \\
\hline N40/B0 & & $x$ & & $x$ & & & $x$ & & \\
\hline N40/RB10 & & $x$ & & & $x$ & & $x$ & & \\
\hline N40/RB20 & & $x$ & & & & $x$ & $x$ & & \\
\hline N40/EB10 & & $x$ & & $x$ & & & & $x$ & \\
\hline N40/EB20 & & $x$ & & $x$ & & & & & $x$ \\
\hline N80/B0 & & & $x$ & $x$ & & & $x$ & & \\
\hline N80/RB10 & & & $x$ & & $x$ & & $x$ & & \\
\hline N80/RB20 & & & $x$ & & & $x$ & $x$ & & \\
\hline N80/EB10 & & & $x$ & $x$ & & & & $x$ & \\
\hline N80/EB20 & & & $x$ & $x$ & & & & & $x$ \\
\hline
\end{tabular}

Table 5. Physical and chemical properties of biochar provided by Austrian company Sonnenerde.

\begin{tabular}{lcccccc}
\hline $\begin{array}{l}\text { Bulk density } \\
\left(\mathrm{g} \mathrm{cm}^{-3}\right)\end{array}$ & $\begin{array}{c}\mathrm{SSA} \\
\left(\mathrm{m}^{2} \mathrm{~g}^{-1}\right)\end{array}$ & $\begin{array}{c}\text { Grain fraction } \\
(\mathrm{mm})\end{array}$ & $\begin{array}{c}\mathrm{SOC} \\
\left(\mathrm{g} \mathrm{kg}^{-1}\right)\end{array}$ & $\mathrm{pH}(\mathrm{KCl})$ & $\begin{array}{c}\text { Total C } \\
(\%)\end{array}$ & $\begin{array}{c}\text { Total N } \\
(\%)\end{array}$ \\
\hline 0.206 & 21.7 & $0-5$ & 10.2 & 8.8 & 53.1 & 14.0 \\
\hline SSA = specific surface area & & & & & &
\end{tabular}


ground biomass at all application amounts $\left(10,20 \mathrm{t} \mathrm{ha}^{-1}\right)$ and fertilizer levels $\left(0,40,80 \mathrm{~kg} \mathrm{~N} \mathrm{ha}{ }^{-1}\right)$. Although these treatments resulted in the same, or lower number of plants per $\mathrm{m}^{2}$, the higher values of vegetation indices indicate larger photosynthetic area of plant canopy that could contribute to higher biomass development and higher final grain yield. Thus the addition of compost improved the positive effect of biochar addition. On the contrary, Schulz et al. (2014) observed no effect of co-composted biochar on sandy substrate and significantly lower biomass yield on loamy substrate in their greenhouse experiment. Also no trend, or tendency, of co-composted biochar influencing plant height was reported. However the amounts of biochar + compost applied by Schulz et al. (2014) were considerably lower than in this experiment, and as a result they suggested application in doses higher than $2.5 \mathrm{Mg} \mathrm{ha}{ }^{-1}$ or biochar activation. Schultz and Glasser (2012) reported significant synergetic effects on plant growth when biochar was combined with mineral fertilizer or compost, highlighting the biochar + compost combination as the most promising for agronomic performance. On the other hand, as compost has only a moderate potential for soil organic matter build-up (Fisher and Glaser, 2012), this effect will likely vary over years.

The increase of canopy development with the RB application was less than that for EB and was not significant in comparison to control. RB applied in combination with $\mathrm{N}$ fertilizer at the highest rate $\left(80 \mathrm{~kg} \mathrm{~N} \mathrm{ha}^{-1}\right)$ increased the crop canopy development (assessed by I-DVI) and crop height. Application of $20 \mathrm{t} \mathrm{ha}^{-1}$ of raw biochar generally resulted in more plants with lower above-ground and below-ground biomass and thus was less suitable treatment for crop production. For the root biomass, the response pattern was similar to above-ground biomass (as observed also by Bruun et al., 2014).

\section{Materials and methods}

\section{Study site}

The field experiment was established in the spring of 2014 at an experimental site in Malanta $\left(48^{\circ} 19^{\prime} \mathrm{N}, 18^{\circ} 09^{\prime} \mathrm{E}\right)$, in the Nitra region of western Slovakia. Prior to the start of the experiment, during the 2013 growing season, the field had been cropped with corn (Zea mays L.) using conventional tillage. The soil type is classified as loamy Typic Hapludalfs (USDA, 1999), resp. Haplic Luvisol according to WRB (2006) classification. Prior to the experiment, soil $\mathrm{pH}(\mathrm{KCl})$ and soil organic carbon (SOC) were determined from randomly collected samples taken at depths $0-10 \mathrm{~cm}$ and $20-30 \mathrm{~cm}$ (Table 3). The soil was acidic and low in SOC. The total $\mathrm{N}$ content was close to $3.5 \mathrm{mg} \mathrm{kg}^{-1}$. Mean annual air temperature was $10.3{ }^{\circ} \mathrm{C}$ in 2014 , with $12.4{ }^{\circ} \mathrm{C}$ during the field trial (April 8 - June 17, 2014) (Figure 1). Although the annual precipitation in 2014 was $18.7 \%$ higher than the long-term mean, precipitation during the field trial was 83.7 $\%$ of the long-term mean.

\section{Experimental field design}

Plots of agricultural land $(4 \mathrm{~m} \times 6 \mathrm{~m})$ were organized into a randomized block design. Fifteen treatment plots, with 3 replicates each, were established to assess the effects of two biochar types in combination with mineral fertilizer (Table 4). The treatments consisted of three different biochar application rates $\left(0,10,20 \mathrm{t} \mathrm{ha}^{-1}\right)$ that were combined with 3 levels of mineral fertilizer - ammonium nitrate $(0,40,80 \mathrm{~kg}$ $\mathrm{N}$ ha $^{-1}$ ). Raw biochar (RB) was produced by Austrian company Sonnenerde from paper fiber sludge and grain husks (1:1) by a process of pyrolysis at $550{ }^{\circ} \mathrm{C}$ for 30 minutes in a Pyreg reactor (Pyreg GmbH, Dörth, Germany). Basic chemical and physical properties of this material provided by the producer can be found in Table 5 . To produce the enriched biochar $(E B)$, the hot RB was sprayed with liquid ammonium sulfate. It was then mixed with fresh compost material consisting of $45 \%$ green waste, $45 \%$ milk sludge and $10 \%$ of stone powder in the ratio $1: 1$, and then composted at a professional compost production facility. The composting process lasted for 8 weeks and the piles were turned over three times per week (Schulz et al., 2013). On March 10, 2014 the raw and enriched biochar were spread onto the soil at the planned application rates and surface incorporated with hand rakes. Ammonium nitrate was applied to fertilized plots in dosages according to experimental plan (Table 4). Biochars and fertilizer were then incorporated into the soil (up to $10 \mathrm{~cm}$ depth) by conventional machinery and on the next day the crop was sown.

\section{Plant material}

Spring barley (Hordeum vulgare L. var. Malz) seeds were sown in rows $12.5 \mathrm{~mm}$ apart at a sowing rate of $190 \mathrm{~kg} \mathrm{ha}^{-1}$ in March 11, 2014. Pesticide post-crop emergence applications included Mustang herbicide (applied at $0.5 \mathrm{I} \mathrm{ha}^{-1}$ on April 23), resp. Tango fungicide $\left(1.0 \mid \mathrm{ha}^{-1}\right)$ and Vaztak insecticide $\left(0.15 \mathrm{I} \mathrm{ha}^{-1}\right)$, both applied on May 22 uniformly at all plots.

\section{Determination of image-derived vegetation indices (I-DVI)}

A modified methodology, as described by Casadesus and Villegas (2012), was applied for the assessment of plant development according to the changing photosynthetic area of canopy. The method entails a non-destructive optical assessment where a conventional digital camera can be used as the device for field trials for various purposes. Two square subplots $\left(1 \mathrm{~m}^{2}\right)$ were randomly located in every plot with the edges of the square marked. The borders of the plot were excluded from the selection to avoid edge effects. A digital camera SONY NEX-3 was attached to a tripod and set at $133.5 \mathrm{~cm}$ from the ground and the objective was focusing on the subplot at an angle of $27^{\circ}$. By adopting this angle, rather than taking vertical images, the tripod could be positioned close to the plot border without disturbing the plant canopy and at the same time the image could capture the whole subplot including the marked plot edges. Photo sampling was performed walking across the field following the subplots according to their spatial arrangement along a preestablished path. From the beginning of April up to midJune, eight digital image photo sessions were taken of each subplot around solar noon to avoid shadows on the images. After downloading, sorting and cropping according to subplot edges, the images were processed in BreedPix software. Image-derived vegetation indices $\left(I-D V I_{n}-\right.$ where $n$ stands for the sampling date) were calculated by the 
percentage of green fraction (GF), which corresponds to the proportion of green pixels in an image, where a pixel is considered green if its hue is within a range of 60 up to $120^{\circ}$ (Casadesús and Villegas, 2014). Besides the values of vegetation indices, the program also produces output images that indicate how the program has interpreted each input image (Figure 2). The GF is kept with its original color while the grey color indicates background that is excluded from counting.

\section{Determination of above and below-ground biomass}

On June 12, after the beginning of the milk development stage, when canopy expansion has reached its maximum (Boys and Geary, 2015), plant sampling was conducted. A shovel was used to remove the soil and plant roots from the top $10 \mathrm{~cm}$ from one randomly selected row $(0.5 \mathrm{~m}$ length) per plot excluding the plot edges. We assumed that the amount of roots from the studied row, which explored neighboring rows was compensated for by roots growing into the studied row. Above-ground biomass was cut from roots and the main stems were selected and stored separately to determine the total number of plants per $\mathrm{m}^{2}$ and the mean crop height. Dry root biomass (at $85 \%$ of dry matter) was determined by wet sieving through $2 \mathrm{~mm}$ sieve and drying in the oven at $60^{\circ} \mathrm{C}$ at least for 5 days until the dry weight was unchanged (Graber et al., 2010). Aboveground dry biomass (foliage and ears) was determined by drying as above. The second plant sampling was conducted at harvest time. Final grain yield was calculated as multiplication of total number of ears per $\mathrm{m}^{2}$, number of grains per ear and average grain weight at $85 \%$ of dry biomass (Boys and Geary, 2015).

The addition of biochar accelerated the start of the individual growth stages. The biggest difference was observed for EB when applied at $20 \mathrm{t} \mathrm{ha}^{-1}$ at all fertilization levels and for the other biochar application types and rates when no fertilizer was applied (data not presented). Thus, when mentioning the growth stages based on $\mathrm{BBCH}$ scale (Boys and Geary, 2015) throughout this paper, the control at three fertilization levels (median) is presented.

\section{Statistical analyses}

Reported results are the means \pm the standard error of the mean (SEM). One-way ANOVA (analysis of variance) at $\mathrm{P} \leq$ 0.05 was carried in order to examine the effect of biochar and fertilizer application on I-DVI $(n=6)$, plant height, number of plants per $\mathrm{m}^{2}$, above ground and below ground biomass $(n=3)$, respectively. Significant differences between control and treatments were identified using the Fisher's least significant difference test (at $P \leq 0.05$ ) in STATGRAPHICS Centurion XV v. 15.1.2 software.

\section{Conclusion}

The EB treatment combined with compost was shown to have a better effect on plant growth than RB and control at all fertilization rates. However, the effect of the RB application at $10 \mathrm{t} \mathrm{ha}^{-1}$ or $20 \mathrm{t} \mathrm{ha}^{-1}$, and at applied fertilization levels $\left(0,40,80 \mathrm{~kg} \mathrm{~N}^{-1}\right)$, did not show clear effects on the plant growth in the first year of application. According to the trend of crop height changes, RB could possibly have an enhancing effect if more $\mathrm{N}$ fertilizer had been applied.

We conclude that a single EB application of $10 \mathrm{t} \mathrm{ha}^{-1}$, or 20 $\mathrm{t}$ ha $\mathrm{a}^{-1}$ even if applied without $\mathrm{N}$ fertilizer, can increase plant biomass on loamy Haplic Luvisols/Typic Hapludalfs at least over the first cropping season. The current results indicate that biochar associated with compost, and especially with adequate levels of additional nitrogen fertilizer, can increase crop growth and dry matter during the vegetative season. The size of the responses in this experiment suggests that similar responses are likely in other agricultural areas.

Because of a moderate potential for soil organic matter build-up with compost, long-term field studies are needed to determine when a steady-state is reached, or if and when a decline starts to occur. To contribute to this research, our monitoring of the effect of commercially available biochar amendment will be continued for at least another two seasons. We will determine what the plant response (corn and winter wheat) will be in the following years after biochar application.

\section{Acknowledgements}

This study was financially supported by projects VEGA 1/0268/14, APVV 0512-12, KEGA 019SPU-4/2017 and KEGA 026SPU-4/2017. We also acknowledge Martin Lukac for advice at the fieldwork planning and Wayne Meyer, Deniz Aydın and Brent Clothier for proof checking and valuable comments on the paper.

\section{References}

Alburquerque JA, Salazar P, Barrón V, Torrent J, del Carmen del Campillo M, Gallardo A, Villar R (2013) Enhanced wheat yield by biochar addition under different mineral fertilization levels. Agron Sustain Dev. 33(3):475-484.

Bajgai Y, Kristiansen P, Hulugalle N, McHenry M (2015) Comparison of organic and conventional managements on yields, nutrients and weeds in a corn-cabbage rotation. Renew Agr Food Syst. 30(2):132-142.

Boys E, Geary F (2015) Barley growth guide. AHDB Cereals \& Oilseeds, Kenilworth, UK. pp. 1-24.

Bruun EW, Petersen CT, Hansen E, Holm JK, HauggaardNielsen H (2014) Biochar amendment to coarse sandy subsoil improves root growth and increases water retention. Soil Use Manage. 30(1):109-118.

Casadesus J, Villegas D (2012) Biomass assessment for cereal breeding using vegetation indices obtained with conventional digital cameras. http://www.ub.edu/optichinagriculture/data/uploads/wor kshop2/presentations/casadesus-irta.pdf. 2012 September 14; Accessed on $20^{\text {th }}$ February 2015.

Casadesús J, Villegas D (2014) Conventional digital cameras as a tool for assessing leaf area index and biomass for cereal breeding. J Integ Plant Biol. 56(1):7-14.

Delibacak S, Ongun AR (2016). Influence of treated sewage sludge application on corn and succeeding wheat yield and some properties of sandy clay soil. Turk J Field Crops. 21(1):1-9.

Duxbury J, Lyons G, Bruulsema T (2015) Human health depends on soil nutrients. Better Crops with Plant Food. 99(1):7-9. 
FAO (2015) FAO and the post-2015 development agenda. http://www.fao.org/sustainable-developmentgoals/overview/fao-and-the-post-2015-developmentagenda/en/. Accessed on $2^{\text {nd }}$ January 2016.

Fischer D, Glaser B (2012) Synergisms between compost and biochar for sustainable soil amelioration. In: Sunil K, Bharti A (ed) Management of Organic Waste. Tech, Rijeka, Croatia. 167-198.

Graber ER, Meller Harel Y, Kolton M, Cytryn E, Silber A, Rav David D,Tsechansky L, Borenshtein M, Elad Y (2010) Biochar impact on development and productivity of pepper and tomato grown in fertigated soilless media. Plant Soil. 337(1-2):481-496.

Lal $R$ (2009) Soil degradation as a reason for inadequate human nutrition. Food Sec. 1(1):45-47.

Lehman J, Gaunt J, Rondon M (2006) Bio-char sequestration in terrestrial ecosystems - a review. Mitigation and Adaptation Strategies for Global Change. 11:395-419.

Lin XW, Xie ZB, Zheng JY, Liu Q, Bei QC, Zhu JG (2015) Effects of biochar application on greenhouse gas emissions, carbon sequestration and crop growth in coastal saline soil. Eur J Soil Sci. 66:329-338.

Liopa-Tsakalidi A, Barouchas PE (2017) Effects of biochar on pepperoncini (Capsicum annuum L. CV. Stavros.) germination and seedling growth in two soil types. Aust J Crop Sci. 11(2):264-270.

Mayer J, Gunst L, Mäder P, Samson M, Carcea M, Narducci V, Thomsen IK, Dubois D (2015) Productivity, quality and sustainability of winter wheat under long-term conventional and organic management in Switzerland. Eur J Agron.65:27-39.

Morgounov A, Gummadov N, Belen S, Kaya Y, Keser M, Mursalova J (2014) Association of digital photo parameters and NDVI with winter wheat grain yield in variable environments. Turk J Agric For. 38(5):624-632.

Ramola S, Srivastava RK, Vasudevan P (2013) Effect of biochar application in combination with domestic wastewater on biomass yield of bioenergy plantations. International Journal of Energy Sector Management. 7(3):355-363.

Schulz H, Dunst H, Glaser B (2013) Positive effects of composted biochar on plant growth and soil fertility. Agron Sustain Dev. 33(4):817-827.

Schulz H, Dunst H, Glaser B (2014) No effect level of cocomposted biochar on plant growth and soil properties in a greenhouse experiment. Agronomy. 4(1):34-51.

Schulz H, Glaser B (2012) Effects of biochar compared to organic and inorganic fertilizers on soil quality and plant growth in a greenhouse experiment. J Plant Nutr Soil Sci. 175(3):410-422.

Sohi SP, Krull E, Lopez-Capel E, Bol R (2010) Chapter 2 - A review of biochar and its use and function in soil. Adv Agron. 105:47-82.

UNEP (2012) GEO5 - Global Environmental Outlook. Environment for the future we want. United Nations Environment Programme, Progress Press Ltd, Malta. http://web.unep.org/geo/sites/unep.org.geo/files/docum ents/geo5_frontmatter.pdf. Accessed on $25^{\text {th }}$ October 2016.

USDA (1999) Soil Taxonomy: A basic system of soil classification for making and interpreting soil surveys. $2^{\text {nd }}$ ed. Agriculture Handbook No. 436. http://www.nrcs.usda.gov/Internet/FSE_DOCUMENTS/nrc s142p2_051232.pdf. Accessed on $11^{\text {th }}$ November 2015.

WRB (2006) World reference base for soil resources 2006. $2^{\text {nd }}$ edition. World soil resources reports No. 103, FAO, Rome, $112 \mathrm{pp}$. 